\title{
航空市場でのハブ・スポークネットワーク形成 と空港使用料政策に関する研究
}

\author{
大橋 忠宏 ${ }^{1}$ 安藤 朝夫 ${ }^{2}$ \\ 1正会員 博士(情報科学) 運輸政策研究所研究員 (財)連輸政策研究機構 ( $\bar{\top} 105-0001$ 東京都港区虎ノ門3-18-19) \\ ${ }^{2}$ 正会貝 Ph.D. 東北大学大学院助教授 情報科学研究科 (广980-8577仙台市青葉区片平2-1-1)
}

\begin{abstract}
航空市場には空港管理者と航空会社, 旅客が主体として関与している. 既存研究では, 航空会社毎の路線網を所与 とした上で, 旅客市場に限定して分析が行われることが多い. 従って, ハブ・スボークネットワークの形成要因や空 港使用料政策に関してはこれまで理論的には殆ど議論されてこなかった，本稿では航空市場参加主体の行動に基つい たモデルを構築し，ハブ・スポークネットワークか形成される条件，及び空港使用料政策が市場構造に与える影響に ついて考察を行う.
\end{abstract}

Key Words: hub-spoke network, landing fee, scale economies from aircraft size, alternative mode

\section{1.序論}

航空市場には空港管理者と複数の航空会社·多数の旅 客が主体として関与しており, 各主体の行動結果として 航空ネットワークが形成されると考えることは当然のこ とであろう。米国では1978年航空規制緩和法成立以降, ネットワークのハブ・スポーク化が進んだ1)。しかし，そ の形成要因については，必ずしも理論的に明らかにされ ていない!、筆者の知る限り, ハブ・スポークネットワー クの形成要因について, 理論的な検討を行っている研究 には, Hendricks et al.(1995)放ある. 彼らは, Brueckner and Spiller(1991) 万の呼ぶ輸送密度の経済性（付録1）特定化の 一例として, 路線数に比例した固定費用を考慮した利潤 関数を用いて，ハブ・スポークネットワークが形成され るような固定費用の存在を示している. ただし, この固 定費用の想定が曖昧であり，旅客の時間費用が考慮され ていない等の問題もある. 同様に工学的な研究で, 例之 ばHansen $\left.(1990)^{8}\right)$ が, ハブ・スポークネットワークを構築 する航空会社とpoint-to-pointネットワークを構築する航空 会社のそれぞれの行動をゲーム論的に記述することを試 みているが, ハブ・スポークネットワークの形成要因は明 らかにされていない. また，スケジューリング等に関す る研究)でもその形成要因は明らかにされていない.

1 ネットワークを考慮した既存研究の多く223,4,9、では，路線網を ハブ・スポークネットワークに限定し分析が行われている. すな わち, これらでは, ハブ・スポークネットワークが形成されない 状況の下で議論を行っている可能性がある. さらに, ネットワー ク特性としての路線間の代替・補完関係や旅客の時間費用が十分 考虑されていない等の問題もある。
他方近年，日本を含む多くの国々で空港運営，上りわ け空港発着枠制約の問題と空港整備のあり方についての 見直しが進められている。棟における空港発着枠制約 の問題は，国内航空に競争政策を導入できない根拠の一 つとして指摘されている。空港運営に関して中条他 (1995) $)^{10)}$ では，日本の空港整備制度に対して，現行の空港 整備特別会計では，空港間の内部補助が各空港の受益と 負担の関係を曖昧にする故, 効率の点でも負担の公平の 点でも望ましくないと言うだけでなく，各空港の自由裁 量を制限することによって, 空港の発展をも阻んでいる とされている. 特に，(I)全国一律の空港使用料 ${ }^{2}$ ，(II)本来 各空港に帰属すべき燃料税収の問題点が指摘され，空港 の独立採算制や空港使用料の弾力化・自由化等力隄案さ れている. 日本や欧州と比へ，比較的空港発着枠に余裕 のある米国でもシカゴのオへア空港等では空港発着枠制 約の問題が深刻である。この現象が1社による空港独占及 び混雑をもたらし, 当該空港発着路線における独占運顀 設定への懸念1)や弾力的空港使用料採用による混雑緩和へ の提案 ${ }^{12}$ もある。

空港発着枠問題の解決策として, 空港民営化の動きも 観られる．例えば，英国では主要空港の完全民営化と地 方空港の株式会社化が実施された，そしてロンドン地域 の空港ではピークロードプライシングが適用されている ${ }^{33}$ さらにオーストラリアやカナダでも空港民営化が進めら れている(14).

これに対し理論的分析は，航空旅客市場に関するもの

2 厳密に言えば, 成田空港や関西国際空港のように一部の空港で は個別に設定されている. 
が殁どであり，空港使用料に関する分析は，筆者の知る 限りOum et al.(1996) ${ }^{14} k よ り$ 行われているに過ぎない. そ こではハブ・スポークネットワークに限定し, 集権・分 権的な場合について総余剰を最大化するような空港使用 料をつけた場合, 集権的な場合には八ブ空港とその末端 空港間で内部補助が行われるという結果が示されている. しかし，旅客の時間費用が考慮されておらず, 航空会社 の費用も考慮されていない。

このような背景の下, 航空市場構造や航空政策に関し て分析を行うためには，まずハブ・スポークネットワー クの形成要因を明らかにすることが本質的に重要である.

さらに, 航空市場構造を解明する上で, 空港発着枠に関 する資源配分の問題を無視することはできない.そこで, 空港発着枠に関する資源配分問題として, 空港使用料政 策を扱う必要がある. 従って, より全体的な問題として, ハブ・スポークネットワークの形成と空港使用料政策を同 時に論じることが必要であると考えられる.

我々はこれまで路線間の代替・補完関係を考慮したモ デルを構築し, 社会的最適と市場均衡間の関係を考察し, 数值解析を通じて航空政策の役割について考察を行った ${ }^{19}$. そこでは, 既存研究で指摘されている航空会社の費用特 性としての輸送密度の経済性等は考慮されていない。従 って, 航空市場をモデル化する場合に既存研究で指摘さ れているこれらの特性を考慮することは必要である.

本研究ではまず，どのような状況下でハブ・スポーク ネットワーク形成されるのかを明らかにする. 次に空港 使用料に関する一考察として, 全空港一律の空港使用料 がつけられる場合と空港毎に異なる空港使用料がつけら れる場合との間の社会的厚生の比較及び空港間の内部補 助の可能性について明らかにする，以下複数機種を導入 することで機材規模の経済性を考慮したモデルを構築し, 数值分析を通じて前述の主題に接近する. 直感的には, 全空港一律使用料が設定されることは，空港別に異なる 使用料が設定される場合と比較して, 実行可能領域を限 定するだけで社会的厚生の観点から望ましくないことは 想像に難くない.しかし空港運営に関して,これまで理 論的には殆と議論されていない. 従って, 全空港一律使 用料の問題について理論的に明らかにすることは，今後 日本の空港運営問題に関する議論を行う上で重要な課題 であると言えよう。

\section{2.モデル}

\section{（1）航空市場についての仮定}

本研究では，航空市場を図一にに示すように「空港発着 枠市場と旅客市場を包含する市場」と定義する．前者は， 空港管理者と複数の航空会社との間の空港発着枠に関す る市場であり，後者は多数の旅客と航空・代替モード間

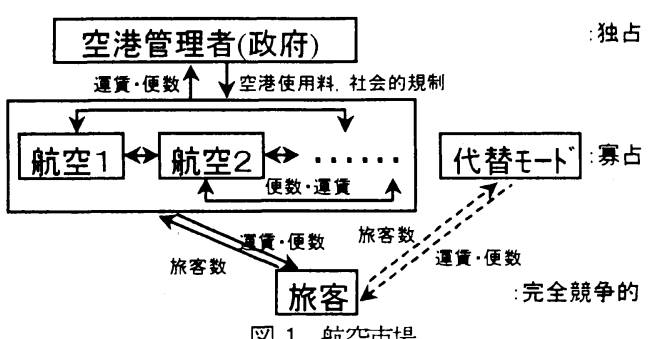

図-1 航空市場

表-1 記号の定義

\begin{tabular}{|c|c|c|c|}
\hline 発地番号 & $\bar{i}$ & 機材の種類 $m$ の集合 & $M$ \\
\hline 着地番号 & $j$ & 企業全体(代替モド含む)の集合 & $A$ \\
\hline リンク番号 & $l$ & 航空会社全体の集合 & $A_{4}$ \\
\hline ルート番号 & $r$ & 与之られた $O D(i, j)$ に対応寸るルー & $R(i, j)$ \\
\hline ノード番号 & $n$ & トからなる集合 & \\
\hline 企業番号 & $a$ & 与えられた & $L(r)$ \\
\hline iまたはj全体の集合 & $I$ & 要素からなる集合 & \\
\hline 全体の集合 & $L$ & 所与の下でのハ両端のノードを表 & $N(l)$ \\
\hline$r$ 全体の集合 & $R$ & 与集合 & \\
\hline$n$ 全体の集合 & $N$ & 空港 $几$ を利用するに表す変換” & $N(n)$ \\
\hline
\end{tabular}

${ }^{*} N^{-1}(n)=\left\{l \mid\left(n, n^{\prime}\right) \in N(l)\right\} \cup\left\{l \mid\left(n^{\prime}, n\right) \in N(l)\right\}$ : 逆変換の記号を用 いているが数学的意味での逆変換ではない.

の座席に関する市場である.この航空市場に関して, 次 のような仮定を導入する.

(M1)ノードとは空港や駅のような交通結節点，リンクと は2つのノードを結ぶ路線のことである。ルートレは 単なるリンクの組み合わせではなく，任意のOD間を 結ぶリンク・企業の組み合わせを指す ${ }^{3}$. ルート全体 がネットワークを構成するものと考える.

(M2)旅客のOD交通量は外生的に与えられ，ルート交通量 はリンクでの運賃や便数の変化に対し弾力的である.

(M3)航空会社はA社 $(a=1,2, \cdots, A)$ 存在し，すべてのリン クに代替モードが存在する，代替モードは，旅客市場 の需給を整合させるために導入されるが, 需要の変化 ，に対して運賃・便数は変化せず，需要に見合うだけの 交通サービスが供給される。こうした代替モードをま とめて $a=0$ で表記する.

(M4)空港使用可能時間は空港により異ならず, 長さTの特 定の時間帯に制限されている.

(M5)複数の企業が特定のリンクを運航するならば，その 運航間隔は旅客のスケジュール調整コストに関し各企 業毎に等間隔とし，個々のリンクでは企業毎にマーケ ットセグメンテーションがなされる4

(M6)航空会社は保有機種・機材数を選択し，その機材を 用いて路線での運航を行うが, ある特定の路線におい

\footnotetext{
3 本稿で “企業”とは各航空会社及び代替モード運営主体を指す (図-2に模式図を示す)．

4 簡単のための仮定であるが, 羽田一福岡間等のスケジュールは, 航空会社毎にほほ等間隔であり，一次近似としてはかなり現実と 適合していると言えよう。この他にも最近の事前購入割引制度や FFP等が普及すれば，(M5)は容認されよう（大橋·安藤(1996)）。
} 
て航空会社か渗入する際，一路線一機種とする。これ は仮定(M5)に矛盾しないために導入する.

(M7)等間隔運航がなされている限り，スケジューリング

について矛盾は生じない.

以下，モデルの説明では，表-1に示す記号を用いる。

\section{(2)旅客}

旅客の行動は大橋·安藤(1996) と同様にランダム効用最 大化問題として考える (付録2）．その結果, 旅客のルート 選択確率 $P^{r}$ は，ロジットモデルで表現される(1).

$$
P^{r}=\frac{\exp \omega\left(-p^{r}-\alpha t^{r}\right)}{\sum_{r \in R(i, j)} \exp \omega\left(-p^{r}-\alpha t^{r}\right)} \text { for } r \in R(i, j)
$$

ただし，p'はルートの総運賃である，従って，ルート交通 量メは,このPrを用いて以下のように書ける.

$$
x^{r}=O D_{i j} P^{r} \text { for } r \in R(i, j)
$$

\section{(3)航空会社}

個々の航空会社の行動も, 基本的には大橋·安藤(1996) と同様に以下の仮定を設ける.ここでは，複数機種導入 による変更点を中心に説明する.

(A1)航空会社は利潤の最大化を行う.

(A2)航空会社間の競争は, ナッシュ的に行われる5.

(A3)便数は連続変数として扱える ${ }^{6}$.

(A4)運航便数は, 上下同数とする.

(A5)仮定(M6)から，1便当たりの運航費用は各リンクで航 空会社により異ならない.

まず, 航空会社の保有機材数 $K_{a}^{m}$ を用いて航空会社の 機材制約は，以下のように修正される.

$$
\sum_{l \in \Omega(a)}\left(t_{a}^{l}+T S\right) f_{a m}^{l} \leq K_{a}^{m} T \text { for } a \in A_{-0}
$$

ここに, TS：1便当たりの機材整備時間， $\Omega(a)$ はすべて のルートrに含まれるリンクに内, 航空会社 $a$ が簐航する リンクの集合, すなわち $\Omega(a)=\{l(l, a) \in L(r), \forall r\}$.

次に，モデルの表現上，旅客と航空会社の需給の関係 式は, $V_{m}$ : 機材容量, $x_{a}^{l}$ : 企業 $a$ のリンク交通量とする とき以下のように表される。

$$
x_{a}^{l}=\sum_{r \in\{r(l, a) \in L(r)\}} x_{m \in M}^{r} \leq f_{a m}^{l} V_{m}
$$

(A6)1便当たりの運航費用 $O C_{a m}^{l}$ は機種 $m$ により異なると し, 以下の関係を機材規模の経済性とよぶこととする。

5 (1),(1')に航空会社間の競争関係が反映される. “ナッシュ的に” とは, 当該航空会社か浰閏最大化を行う際, 自己の運貨·便数の 変化に対して, 他の航空会社・代替モード等の運顀·便数が変化 しないと推測することを意味する.

${ }^{6}$ (A3)により，条件式の限界的な解釈が可能となる．例えば，週 1 便を 1 日当たりに換算すると 0.14 便旧であり，実祭は離散変 数であるが軏続变数のように扱之る．同様に，1 年間当たりの便 数は十分大きな值であり，(A3)は容認されよう.

$$
O C_{a m^{\prime}}^{l}>O C_{a m}^{l} \text { and } O C_{a m^{\prime}}^{l} / V_{m^{\prime}}<O C_{a m}^{l} / V_{m} \text { if } V_{m^{\prime}}>V_{m}
$$

(A7)着陸上離陸に要する使用料は同じであるとする.

$H_{n m}$ を 1 便当たりの離・着陸料， $H_{m}^{l}$ を路線 1 便当た りに換算した空港使用料とすると，その関係は以下のよ うに示される。

$$
H_{m}^{l}=\sum_{n \in N(l)} H_{n m}
$$

一路線一機種の仮定から以下の関倸か成立する.

$$
\prod_{m \in M} f_{a m}^{l}=0
$$

以上の仮定の下, 航空会社 $\left.\left(a \in A_{\downarrow}\right) 0\right)$ 利潤関数を

$$
\begin{gathered}
\pi_{a}=\sum_{l \in \Omega(a)}\left\{p_{a}^{l} x_{a}^{l}-\left(H_{m}^{l}+O C_{a m}^{l}\right) f_{a m}^{l}-S C_{a}^{l} x_{a}^{l}\right\} \\
-\sum_{m \in M} k_{m} K_{a}^{m}-F C_{a}
\end{gathered}
$$

とするとき，航空会社は以下の問題に直面する7.

$$
\max _{p_{a}^{l}, f_{a n}^{l}, K_{a}^{m} \geq 0} \pi_{a} \quad \text { s.t. (2),(3),(5) }
$$

ここに, $p_{a}^{l}$ : 運賃, $F C_{a}$ : 固定費用, $S C_{a}^{l}$ : 旅客1人 当たりのサービス費用, $k_{m}$ : 1 機材当たりに要する費用上 する. (7)のラグランジュ関数をゆ ${ }_{a}$ とし，(2),(3),(5)のラグ ランジュ乗数をそれぞれ $\lambda_{a}^{m}, \mu_{a}^{l}, \delta_{a}^{l}$ とする. Kuhn-Tucker 条件から, 運賃・便数・保有機材数が共に正のとき，1 階の条件は,

$$
\begin{gathered}
\frac{\partial \Phi_{a}}{\partial p_{a}^{l}}=x_{a}^{l}+\sum_{l^{\prime} \in \Omega(a)}\left(p_{a}^{l^{\prime}}-S C_{a}^{l^{\prime}}-\mu_{a}^{l^{\prime}}\right) M 1^{l^{\prime} a}=0 \\
\frac{\partial \Phi_{a}}{\partial f_{a m}^{l}}=\frac{\alpha T}{4\left(\sum_{m \in M} f_{a m}^{l}\right)^{2}} x_{a}^{l}-\left(H_{m}^{l}+O C_{a m m}^{l}\right) \\
-\lambda_{a l}^{m}\left(t_{a}^{l}+T S\right)+\mu_{a}^{l} V-\delta_{a}^{l} \prod_{\substack{m \in \in M \\
m \neq \neq}} f_{a m m^{\prime}}^{l}=0 \\
\frac{\partial \Phi_{a}}{\partial K_{a}^{m}}=-k_{m}+T \lambda_{a}^{m}=0
\end{gathered}
$$

と書くことができる (付録3参照) 。 $\lambda_{a}^{m}$ は機材を使用す るための単位時間当たり限界費用， $\mu_{a}^{l}$ は1座席当たりの 旅客にとっての限界価値或いは航空会社が1座席多く供給 するための限界費用と解釈される。

式(8)或いは式(9)は, 限界的な運賃或いは便数の変化に 対する航空会社の限界収入と限界費用が等しくなること を意味する. 式(10)は1機材当たりの購入（或いはリース） 費用は，機材の機会費用に等しいことを意味する。

\section{（4)空港管理者}

空港運営利潤, 空港容量制約, 社会的厚生関数を以下の ように定義する.

7 本稿で，代替モードは旅客数に応じた費用を負担する，代替モ 一ドの利潤関数は，式(6)に倣って次のように設定される。

$$
\left.\pi_{0}=\sum_{l \in \Omega(0)}\left(p_{0}^{l} x_{0}^{l}-O C_{0 m}^{l}\right) f_{0 m}^{l}-S C_{0}^{l} x_{0}^{l}\right\}-F C_{0}
$$




$$
\begin{gathered}
G_{n}=\sum_{m \in M}\left(H_{n m}-G C_{n m}\right) \sum_{(l, a) \in\left\{(l, a) l l \in N^{-1}(n), a \in A_{-0}\right\}} f^{l} \\
-A_{n} C A P A_{n} \\
\sum_{\substack{(l, a) \in\left\{(l, a) ! \\
l \in N^{-1}(n), a \in A_{0}\right\}}} \sum_{m \in M} f_{a m}^{l} \leq C A P A_{n} \text { for } n \in N
\end{gathered}
$$$$
W=\sum_{i, j \in I} O D_{i j} \frac{1}{\omega} \sum_{r \in R(i, j)} \exp \omega\left(U_{i j}-B^{r}\right)+\sum_{a \in A} \pi_{a}+\sum_{n \in N} G_{n}
$$

ここに, $G C_{n m}$ : 1 便当たりに要する空港費用（例えば管 制に要する費用）， $A_{n}$ : 空港容量維持単位費用或いは空港 建設に伴う利子支払い, $C A P A_{n}$ : 空港nの離発着容量とする. 社会的厚生関数は，3種類の主体の便益の和として式(13) のように定義される (付録4参照). 式(13)右辺第 1 項は, 旅客の消費者余㮃，第2項は航空及び代替モードの利潤の 和, 第3項は空港運営利潤の和を表す.

空港管理者には，ここでは政府を想定する．大橋・安 藤(1996)では，空港管理者の行動に関して空港を所有する 政府に委任された各空港毎の管理者が必要最小限空港を 維持し得るような空港使用料を徽収すると仮定していた。 しかし，空港所有者を政府と想定する以上，政府がその ような消極的な行動を採るよりは，むしろ積極的に社会 的厚生を最大化するような空港使用料設定を行うと考え るのが自然であろう. 従って, ここでは政府は, システ 厶全体で空港運営利潤非負制約・空港容量制約の下で社 会的厚生が最大となるように空港使用料を決定するもの とする（付録5）。すなわち，政府の直面する問題は，

$$
\max _{H_{n m} \geq 0} W\left(H_{n n}, \eta_{a}\left(H_{n m}\right)\right) \text { s.t. (12), } \sum_{n \in N} G_{n} \geqq 0
$$

のように表すことが出来る。ここで，

$$
\begin{aligned}
\eta_{a}\left(H_{n m}\right)= & \left\{\left(p_{a}^{l}, f_{a m}^{l}, K_{a}^{m} \mid p_{a^{\prime}}^{l}, f_{a^{\prime} m}^{l}, K_{a^{\prime}}^{m}, H_{n m}\right)\right. \\
& \left.1 \max _{p_{a}^{l}, f_{a m}^{l}, K_{a}^{m} \geq 0} \pi_{a}, \text { s.t. (2), (3), (5) }\right\}
\end{aligned}
$$

とする. ラグランジュ関数を $\Psi$, 空港運営利潤非負制約, (12)のラグランジュ定数をそれぞれ $\theta ， \tau_{n}$ とすると,

Kuhn-Tucker条件より $H_{n n}>0$ のき，一階の条件は以下の ように書ける。

$$
\begin{aligned}
& \frac{\partial \Psi}{\partial H_{n m}}=\sum_{a \in A_{-0}}\left[\sum_{l \in \Omega(a)}\left(\frac{\partial W}{\partial p_{a}^{l}} \frac{\partial p_{a}^{l}}{\partial H_{n m}}+\frac{\partial W}{\partial f_{a m}^{l}} \frac{\partial f_{a m}^{l}}{\partial H_{n m}}\right)\right. \\
& \left.+\frac{\partial W}{\partial K_{a}^{m}} \frac{\partial K_{a}^{m}}{\partial H_{n m}}\right]-\sum_{n^{\prime} \in N} \tau_{n^{\prime}} \sum_{\substack{(l, a) \in\left\{(l, a) ! \\
l \in N^{-1}(n), a \in A_{-0}\right\}}} \frac{\partial g_{n^{\prime}}}{\partial f_{a m}^{l}} \frac{\partial f_{a}^{l}}{\partial H_{n m}} \\
& +\theta\left[\frac{\partial G_{n}}{\partial H_{n m}}+\sum_{\substack{n^{\prime} \in N \\
(l, a) \in\left\{(l, a) ! \\
l \in N^{-1}\left(n^{\prime}\right), a \in A_{-0}\right\}}} \frac{\partial G_{n^{\prime}}}{\partial f_{a m}^{l}} \frac{\partial f_{a m}^{l}}{\partial H_{n m}}\right]=0 \\
& \text { ただし, } g_{n}=C A P A_{n}-\sum_{(l, a) \in\left\{(l, a) l l \in N^{-1}(n), a \in A_{-}\right\}} f_{a}^{l} \text { とおく. }
\end{aligned}
$$

ここで $\tau_{n}$ は追加的に必要な 1 便当たりの社会的な空港使 用料, $\theta$ は空港運営利潤の社会的重みと解釈される.式(15) は限界的空港使用料の変化に対する航空運賃 - 便数 - 保
有機材数への変化を通じた市場参加主体の限界便益の和 に空港運営利潤の社会評価額を加えたものが空港発着枠 の社会的評価額に等しくなることを意味する.

\section{(5)市場の未知変数と均衡条件}

市場全体での均衡条件式を整理し列举する上，

a) 旅客

旅客の行動から条件式として，OD交通量 $\left(O D_{i j}\right.$ とル 一ト交通量に関する式,

$$
O D_{i j}=\sum_{r \in R(i, j)} x^{r} \quad \text { for } i, j \in I
$$

及び式(1)，(1’)が得られる。しかし式(1)，(1’)が満 たされるならば，OD交通量とルート交通量の関倸 式は必然的に満たされ，条件式としては冗長となる。 したがって, 旅客の行動から得られる条件式は式(1), (1')となる。

\section{b)航空会社}

個々の航空会社の利潤最大化行動加ら得られ\% Kuhn-Tucker条件として，以下の条件式が得られる。

\section{航空運貨 :}

$$
p_{a}^{l} \cdot \frac{\partial \Phi_{a}}{\partial p_{a}^{l}}=0, \frac{\partial \Phi_{a}}{\partial p_{a}^{\prime}} \leq 0, p_{a}^{\prime} \geq 0 \text { for } a \in A_{-0}, l \in \Omega(a)
$$

航空便数 :

$f_{a m}^{l} \cdot \frac{\partial \Phi_{a}}{\partial f_{a m}^{l}}=0, \frac{\partial \Phi_{a}}{\partial f_{a m}^{l}} \leq 0, f_{a m}^{l} \geq 0$ for $a \in A_{-0}, l \in \Omega(a), m \in M$

保有機材数：

$$
K_{a}^{m} \cdot \frac{\partial \Phi_{a}}{\partial K_{a}^{m}}=0, \frac{\partial \Phi_{a}}{\partial K_{a}^{m}} \leq 0, K_{a}^{m} \geq 0 \quad \text { for } a \in A_{-0}, m \in M
$$

機材制約：

$$
\lambda_{a}^{m} \cdot \frac{\partial \Phi_{a}}{\partial \lambda_{a}^{m}}=0, \frac{\partial \Phi_{a}}{\partial \lambda_{a}^{m}} \geq 0, \lambda_{a}^{m} \geq 0 \text { for } a \in A_{-0}, m \in M
$$

需給制約：

$$
\mu_{a}^{\prime} \cdot \frac{\partial \Phi_{a}}{\partial \mu_{a}^{l}}=0, \frac{\partial \Phi_{a}}{\partial \mu_{a}^{l}} \geq 0, \mu_{a}^{\prime} \geq 0 \text { for } a \in A_{-0}, l \in S 2(a)
$$

一路線一機種制約:

$$
\delta_{a}^{l} \cdot \frac{\partial \Phi_{a}}{\partial \delta_{a}^{l}}=0, \frac{\partial \Phi_{a}}{\partial \delta_{a}^{l}} \geq 0, \delta_{a}^{l} \geq 0 \text { for } a \in A_{-0}, l \in \Omega(a)
$$

\section{(c) 空港管理者}

空港管理者の直面する問題の Kuhn-Tucker条件上 して以下の条件式が得られる。

\section{空港使用料：}

$H_{n m} \cdot \frac{\partial \Psi}{\partial H_{n m}}=0, \frac{\partial \Psi}{\partial H_{n m}} \leq 0, H_{n m} \geq 0$ for $m \in M, n \in N\left(15^{\prime}\right)$ 空港容量制約:

$$
\tau_{n} \cdot \frac{\partial \Psi}{\partial \tau_{n}}=0, \frac{\partial \Psi}{\partial \tau_{n}} \geq 0, \tau_{n} \geq 0 \text { for } n \in N
$$

空港運営利潤非負制約：

$$
\theta \cdot \frac{\partial \Psi}{\partial \theta}=0, \frac{\partial \Psi}{\partial \theta} \geq 0, \theta \geq 0
$$

(a)-(c)から, ルートの数を $r$, 航空会社数を $A$, リ ンク数をl, 機種数を $m$ 上すると, 式(1),(1')が各 $r$ 本,

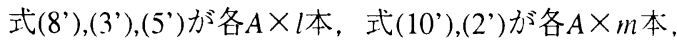


式( $\left.9^{\prime}\right)$ が $A \times m \times l$ 本, 式(15’)が $n \times m$ 本, 式(12')が $n$ 本, 式(16)が1本であり，合わせて， $2 r+3(A \times l)+(A \times m \times$ $l)+2(A \times m)+(n \times m)+n+1$ 本の式が得られる.

\section{(d) 末知変数}

末知変数は $P^{r}, x^{r}, p_{a}^{l}, f_{a m}^{l}, K_{a}^{m}, H_{n m}, \lambda_{a}^{m}, \mu_{a}^{l}, \delta_{a}^{l}, \tau_{n}, \theta$ の計 $2 r+3(A \times l)+2(A \times m \times l)+(A \times m)+(n \times m)+n+1$ 個で あり, 条件式と未知変数の個数は一致する.

\section{3.数値計算と結果の考察}

\section{(1)数値分析の目的と設定}

本研究の目的は, 航空市場の特性, 特に近年話題上な っているハブ・スポークネットワークがどのような状況 下で形成されるのか示すこと，及び空港使用料政策の評 価にある．前述のモデルにおいて，均衡諸変量は，解析 的に陽関数として導出されない. 従って以下, 数值解析 を行うことにより，均衡諸変量を計算し，市場で達成さ れたネットワークの形状を観察する（付録6参照）

数値分析では, 図-2 に示すようにノード数, 可能なり ンクの組み合わせ等を外生的に与えている，まずノード 数は3で, それぞれの地理的位置として(1)大阪, (2)仙台, (3)福岡を想定している.このとき運航可能な路線数（す なわちリンク数) は 3 であり, 旅客の選択可能なルート には航空・代替モードの乗り継ぎルートも含まれる、ま た，基本ケースに打ける航空会社数は 1 社，すなわち独 占とした．基本ケースのデータを表-2 に示す．ラインホ 一ル時間 (時間) 及び代替モードの運顀（万円）は，現 実に沿った值を設定しているが，その他の OD 交通量等 のデー夕は仮設值である。ここで, $C A P A_{n}$ は，3(3)で用い るデータであり，3(2)ではのとして計算している. 航空会 社の固定費用は, 参入障壁として存在するが, ここでは 0 とし, $A_{n}$ も 0 としている.

数值計算では, 次の $2 つ の$ 追加的仮定を設ける.

仮定 1:路線 1 は航空·代替モード共に乗り継ぎの対象路 線とはならない.すなわち乗り継ぎも含めたルート選択 をするのは $O D_{23}$ の旅客のみとする.

仮定 2: もしも $t_{a}^{l}=t_{a^{\prime}}^{l}, O C_{a m}^{l}=O C_{a^{\prime} m}^{l}, S C_{a m}^{l}=S C_{a^{\prime} m}^{l}$ ならば, $p_{a}^{l}=p_{a^{\prime}}^{l}$ and $f_{a m}^{l}=f_{a^{\prime} m}^{l}$ とする.

( for $a, a^{\prime} \in A_{-0,}, l \in \Omega(a) \cap \Omega\left(a^{\prime}\right)$ ).

仮定1は空港1のみがハブ空港になる可能性があることを 示す便宜上の仮定である. 次に仮定2はある特定路線に複 数の航空会社が運航する場合, 航空会社間でラインホー ル時間及び1便当たり運航費用，旅客1人当たりサービス 費用が同じであるなら運賃と便数は航空会社間で異なら ないことを意味する。これは, 当該路線が塞占の場合, 我々の仮定の下では, 共通に参入している路線において

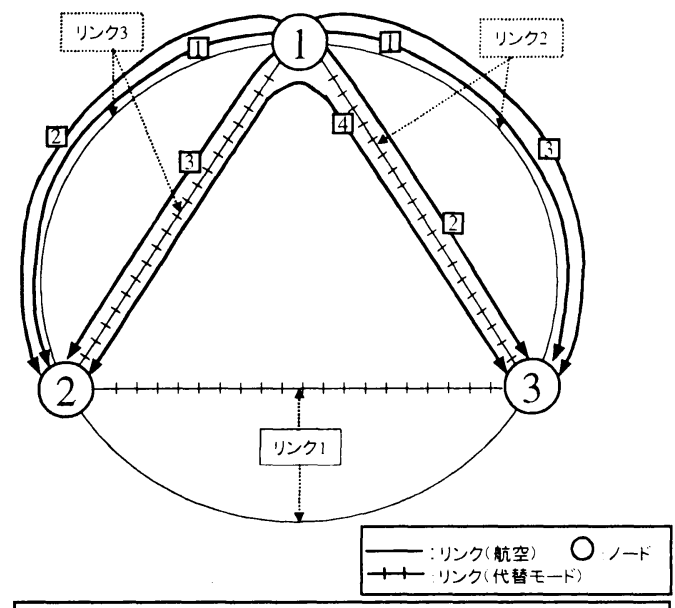

ルートの設定: $\{(1, a), \cdots\}:\{(1,1)\},\{(1,0)\},\{(2,1)\},\{(2,0)\},\{(3,1)\},\{(3,0)\}$,

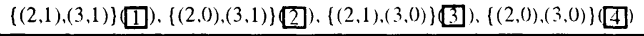

図-2 ノード，リンク，ルート設定(航空旅客市場が独上の場合)

表-2 基本ケースのデー夕

\begin{tabular}{|c|c|c|c|c|c|c|}
\hline \multicolumn{4}{|c|}{ ゾーン/ノードデータ } & \multicolumn{3}{|c|}{ その他のデータ } \\
\hline & 1 & 2 & 3 & & $n t=1$ & $n=2$ \\
\hline 1 & 0 & 8000 & 12000 & $V_{m}$ & $3(x)$ & 150 \\
\hline$O D_{i j} \quad 2$ & 8000 & () & 1000 & $k_{m}$ & $7(0)$ & 450 \\
\hline 3 & 12000 & 1000 & () & & & \\
\hline$C A P A_{n}$ & 50 & 50 & 50 & $T S$ & 0.67 & \\
\hline$G C_{n l}$ & 40 & 40 & 40) & $\alpha$ & 0.2 & \\
\hline$G C_{n 2}$ & 35 & 35 & 35 & $T$ & 15 & \\
\hline
\end{tabular}

リンクデータ
\begin{tabular}{|c|rrr|}
\hline & 1 & 2 & 3 \\
\hline$t_{a}^{l}$ & 2 & 1 & 1.2 \\
$t_{0}^{l}$ & 7 & 2.7 & 4.3 \\
$p_{0}^{l}$ & 3.6 & 1.5 & 2.4 \\
$f_{0}^{l}$ & 2 & 20 & 10 \\
$O C_{a 1}^{l}$ & 80 & 50 & 60 \\
$O C_{a 2}^{l}$ & 70 & 40 & 50 \\
$O C_{0}^{l}$ & 80 & 50 & 70 \\
$S C_{a}^{l}$ & 0 & 0 & 0 \\
$S C_{0}^{l}$ & 0.1 & 0.1 & 0.1 \\
\hline
\end{tabular}

競争の結果，運賃・便数に差が出る唀因が存在しないた めである。ただし，2 社以上か複数の路線に参入か認めら れるなら，航空会社間で路線の棲み分けが生じる可能性 がある.しかし，これは本研究の分析範囲とはせず，仮 定2により排除する.

数值計算を行う上で, どのような状況をハブ・スポー クネットワークと呼ぶのかが䦗題上なる，以下では，八 ブ・スポークネットワークを次のような場合に呼ぶこ上 とする.

定義：航空会社がある特定の1路線で運航しない状況を ハブ・スポークネットワークと呼ぶ.

この定義に, 前述の仮定を加味すると, 本稿では, 航 
空会社が路線 1 で運航しない状況のことをハブ・スポー クネットワークレ呼ぶ。

以下数值計算の前半では, ハブ・スポークネットワー クがどのような状況の下で形成されるのかを中心に考察 する9.この結果は表-3 に示される.ささらに後半では, 空 港使用料政策について分析を行っているが，この数值計 算の結果は表-4,5 に示される.ここで, 航空便数は 1 社 当たりの值を表示している.

\section{(2)ネットワーク形成に関する考察}

ここでは，様々な外生変数の下で達成されるネットワ 一ク形状を通じて, ハブ・スポークネットワークの形成 要因について明らかにする. その際, 空港使用料は外生 的に与えられるものとする．まず，基本ケースとの比較 からケース 14 を観ることで, パラメータの変化が市場構 造に与える影響について考察する. 尚, 表-3 のケース名 右の括弧内は基本ケースから変化させた外生変数の値を 示している.

まずケース 1 から, 旅客の時間価値パラメー夕 $\alpha$ の上 昇は全ての路線で航空運賃・便数を増加させる，さらに 旅客数から $\alpha$ の上昇は航空のシェアを増加させる.

ケース 2 は， $\alpha$ の上昇と代替モード便数が減少した場 合である.このとき, 各路線の航空のシェアは増加し, 乗り継ぎ旅客も増加している. しかし, 独占の場合, こ の他にも代替モードの便数を変化させて計算を行ったが, 代替モードの変化だけではハブ・スポークネットワーク は形成されない.

ケース 3 は機材規模の経済性が弱まった場合の計算結 果である.このとき航空会社により路線 1 で使用機種変 更が行われるだけである.

ケース4はノード 2-3 間の OD 交通量が減少した場合の 結果である. この場合, ハブ・スポークネットワークが 形成されている。 これは，旅客が直行便を利用するより も乗り継ぎ便を利用する方が一般化費用が十分に低くな るためである。

ケース5-7 はケース 2 に更に参入が生じる場合である. この参入の効果については, 社会的厚生も含めてケース 2 と比較する。 このとき, 幹線の一部或いは全路線が複占 になることでハブ・スポークネットワークか形成される.

8 ハブ・スポークネットワーク構築は, 航空会社の戦略という認 識が一般的である. 乗り継ぎ旅客が存在しない場合, すなわち, ここでは $O D_{23}$ の旅客すべてか路線 1 の代替モードを利用する場 合にも, サービス供給側からはハブ・スポークネットワークが形 成されていると言えよう。ただし，このような場合，需要側から はハブ・スポークネットワークが形成されているとは言い難い. 9 仮定 1,2 を設けない場合, すなわち, 3 路線か対等であり, 航 空会社間での路線のすみわけが生じないならば，物理的にハブ. スポークネットワークの形成される可能性は高くなる.

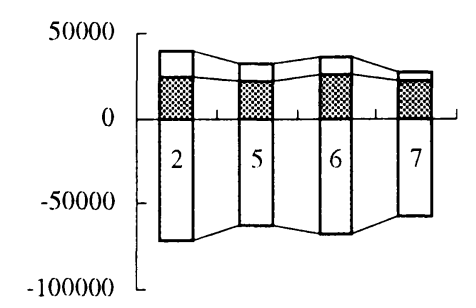

网航空利潤計口代替利潤口旅客の総費用

図-3 ケース 2,5-7 の社会的厚生の構成

この理由は, 運賃の減少上便数の増加により，OD $O D_{33}$ の旅 客が直行便ルートよりも乗り継ぎルートを選択する方が 一般化費用が十分低くなるため)である（図-3）.

ここでケース 5 に比ベケース 6 では, 社会的厚生は減 少している，このここがら幹線の内，代替モードが相対 的に整備されていない路線へ参入が行われる方がそうで ない場合と比較して，社会的厚生の観点加望ましい上 言える。これは代替モードが相対的に整備されていない 路線の方が，旅客の時間費用減少に及ほす効果が大きく なるためである.

紙面の都合上割爱するが， $\alpha$ 小さく，代替モードが 十分整備されている状况の下では，新規参入が行われて もハブ・スポークネットワークが形成されない場合もあ る.ささに航空会社の参入により社会的厚生は悪化する。

以上の結果加結論上して次のことが言える.

「機材規模の経済性の有無に関わらず，乗り継ざルート での旅客の一般化費用が值行便ルートを利用する場合の 一般化費用に比べて十分低い状況の下で，ハブ・スポー クネットワークが形成される.」

乗り継ぎルートの方が直行便ルートよりも旅客の一般 化費用が十分低くなる状況は，(1)幹線への新規参入， (2) 対象上なる市場の中で，他の OD 交通量に比べて相対的 にかなり需要の少ない $\mathrm{OD}$ が存在する場合，に現れる。 この傾向は，旅客の時間価値の上昇や代替モードがあま り整備されていない場合に顕著である。尚，幹線への新 規参入の効果に関して，代替モードがあまり整備されて いない路線へ新規参入が行われる方が，そうでない場合 と比較して旅客の一般化費用の減少の程度が大きいため, 高い社会的厚生を達成することが出来る.

ところで，今回の計算結果加らは，機材規模の経済性 とハブ・スポークネットワーク形成上の関係は確認する ことが出来なかった．ただし，ケース３のように機材規 模の経済性が弱まる場合には，ローカル線でのみ機種変 更が行われ，幹線での使用機種変更は認訲ら机なかった。 このことはCaves et al.(1984)の分析で, ローカル線程, 密 度の経済性が慟くとされていたことと一致していると言 えよう。 
表-3 航空会社のネットワーク形成に関する計算結果例

基本ケース

\begin{tabular}{|r|c|c|r|r|r|}
\hline 路楾 & 航空 & \multicolumn{2}{|c|}{ 航空便数 } & \multicolumn{2}{|c|}{ 旅客数 } \\
\cline { 3 - 6 } & 運貣 & \multicolumn{1}{c|}{$\mathrm{m}=1$} & \multicolumn{1}{c|}{$\mathrm{m}=2$} & 航空計 & 代替 \\
\hline 1 & 3.30 & 1.27 & 0.00 & 382 & 161 \\
2 & 2.28 & 15.98 & 0.00 & 4793 & 7664 \\
3 & 2.87 & 15.05 & 0.00 & 4516 & 3941 \\
\hline
\end{tabular}

\begin{tabular}{|r|r|r|}
\hline 空港 & \multicolumn{2}{|c|}{ 空港使用料 } \\
\cline { 2 - 3 } & $\mathrm{m}=1$ & $\mathrm{~m}=2$ \\
\hline 1 & 40 & 35 \\
2 & 40 & 35 \\
3 & 40 & 35 \\
\hline
\end{tabular}

\begin{tabular}{|c|c|}
\hline \multicolumn{2}{|c|}{ 機材保有数 } \\
\hline $\mathrm{m}=1$ & $\mathrm{~m}=2$ \\
\hline 3.88 & 0.00 \\
\hline
\end{tabular}

$40, G C_{n 2}=20$ for all $n$ )

ケース $3\left(k_{2}=350, O C_{a^{2}}^{1}=30, O C_{02}^{2}=25, O C_{0_{2}}^{3}=40\right.$

\begin{tabular}{|r|r|r|r|r|r|}
\hline 路線 & 航空 & \multicolumn{2}{|c|}{ 航空便数 } & \multicolumn{2}{|c|}{ 旅客数 } \\
\cline { 3 - 6 } & 運貢 & \multicolumn{1}{c|}{$\mathrm{m}=1$} & \multicolumn{1}{c|}{$\mathrm{m}=2$} & 航空計 & 代替 \\
\hline 1 & 3.59 & 0.00 & 2.55 & 382 & 161 \\
2 & 2.28 & 15.98 & 0.00 & 4793 & 7664 \\
3 & 2.87 & 15.05 & 0.00 & 4516 & 3941 \\
\hline
\end{tabular}

ケース $4\left(O D_{13}=300\right)$

\begin{tabular}{|r|c|c|c|r|r|}
\hline 路線 & 航空 & \multicolumn{2}{|c|}{ 航空便数 } & \multicolumn{2}{|c|}{ 旅客数 } \\
\cline { 2 - 6 } & 運賃 & $\mathrm{m}=1$ & $\mathrm{~m}=2$ & 航空計 & 代替 \\
\hline 1 & - & - & - & 0 & 77 \\
2 & 2.27 & 15.81 & 0.00 & 4744 & 7478 \\
3 & 2.85 & 14.78 & 0.00 & 4433 & 3789 \\
\hline
\end{tabular}

ケース 5( $\alpha=0.4$,路線 3 のみ複占, $f_{0}^{1}=2, f_{0}^{2}$

\begin{tabular}{|r|c|c|c|r|r|}
\hline 路線 & 航空 & \multicolumn{2}{|c|}{ 航空便数 } & \multicolumn{2}{|c|}{ 旅客数 } \\
\cline { 3 - 6 } & 運貢 & $\mathrm{m}=1$ & $\mathrm{~m}=2$ & 航空計 & 代替 \\
\hline 1 & - & - & - & 0 & 42 \\
2 & 2.28 & 20.54 & 0.00 & 6162 & 6571 \\
3 & 2.24 & 14.82 & 0.00 & 8424 & 941 \\
\hline
\end{tabular}

ケース $6\left(\alpha=0.4\right.$, 路線 2 の複占, $f^{1}=2, f^{2}$

\begin{tabular}{|r|c|c|c|r|r|}
\hline 路線 & 航空 & \multicolumn{2}{|c|}{ 航空便数 } & \multicolumn{2}{|c|}{ 旅客数 } \\
\cline { 3 - 6 } & 運頧 & $\mathrm{m}=1$ & $\mathrm{~m}=2$ & 航空計 & 代替 \\
\hline 1 & - & - & - & 0 & 73 \\
2 & 1.91 & 16.43 & 0.00 & 9738 & 3622 \\
3 & 3.10 & 19.33 & 0.00 & 5794 & 3016 \\
\hline
\end{tabular}

ケース 7( $\alpha=0.4$, 全路線複占, $\left.f_{0}^{1}=2, f_{0}^{2}=20, f_{0}^{3}=10\right)$

\begin{tabular}{|r|c|c|c|r|r|}
\hline 路線 & 航空 & \multicolumn{2}{|c|}{ 航空便数 } & \multicolumn{2}{|c|}{ 旅客数 } \\
\cline { 3 - 6 } & 運貢 & $\mathrm{m}=1$ & $\mathrm{~m}=2$ & 航空計 & 代替 \\
\hline 1 & - & - & - & 0 & 17 \\
2 & 1.81 & 16.60 & 0.00 & 9956 & 3243 \\
3 & 2.00 & 14.26 & 0.00 & 8556 & 730 \\
\hline
\end{tabular}

\begin{tabular}{|r|r|r|}
\hline 空港 & \multicolumn{2}{|c|}{ 空港使用料 } \\
\cline { 2 - 3 } & $\mathrm{m}=1$ & $\mathrm{~m}=2$ \\
\hline 1 & 40 & 35 \\
2 & 40 & 35 \\
3 & 40 & 35 \\
\hline
\end{tabular}

\begin{tabular}{|r|r|r|}
\hline 空港 & \multicolumn{2}{|c|}{ 空港使用料 } \\
\cline { 2 - 3 } & $\mathrm{m}=1$ & $\mathrm{~m}=2$ \\
\hline 1 & 40 & 35 \\
2 & 40 & 35 \\
3 & 40 & 35 \\
\hline
\end{tabular}

\begin{tabular}{|r|r|r|}
\hline 空港 & \multicolumn{2}{|c|}{ 港使用料 } \\
\cline { 2 - 3 } & $\mathrm{m}=1$ & $\mathrm{~m}=2$ \\
\hline 1 & 40 & 20 \\
2 & 40 & 20 \\
3 & 40 & 20 \\
\hline
\end{tabular}

\begin{tabular}{|c|c|}
\hline \multicolumn{2}{|c|}{ 機材保有数 } \\
\hline$m=1$ & $m=2$ \\
\hline 4.14 & 0.00 \\
\hline
\end{tabular}

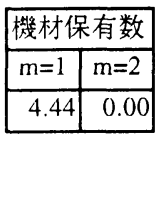

\begin{tabular}{|r|r|r|}
\hline 空港 & \multicolumn{2}{|c|}{ 空港使用料 } \\
\cline { 2 - 3 } & $\mathrm{m}=1$ & $\mathrm{~m}=2$ \\
\hline 1 & 40 & 35 \\
2 & 40 & 35 \\
3 & 40 & 35 \\
\hline
\end{tabular}

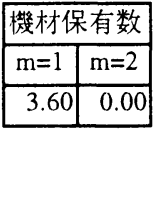

\begin{tabular}{|r|r|r|}
\hline 空港 & 空港使用料 \\
\cline { 2 - 3 } & $\mathrm{m}=1$ & $\mathrm{~m}=2$ \\
\hline 1 & 40 & 35 \\
2 & 40 & 35 \\
3 & 40 & 35 \\
\hline
\end{tabular}

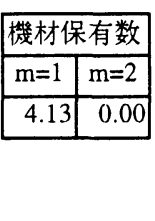

\begin{tabular}{|}
$\left.20, f_{0}^{3}=10\right)$ \\
\begin{tabular}{|r|r|r|}
\hline 空港 & \multicolumn{2}{c|}{ 港使用料 } \\
\cline { 2 - 3 } & $\mathrm{m}=1$ & $\mathrm{~m}=2$ \\
\hline 1 & 40 & 35 \\
2 & 40 & 35 \\
3 & 40 & 35 \\
\hline
\end{tabular}
\end{tabular}

\begin{tabular}{|r|r|r|}
\hline 空港 & \multicolumn{2}{|c|}{ 空港使用料 } \\
\cline { 2 - 3 } & $\mathrm{m}=1$ & $\mathrm{~m}=2$ \\
\hline 1 & 40 & 35 \\
2 & 40 & 35 \\
3 & 40 & 35 \\
\hline
\end{tabular}

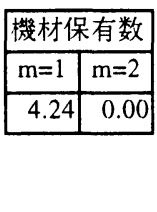

\begin{tabular}{|c|c|}
\hline $\mathrm{m}=1$ & $\mathrm{~m}=2$ \\
\hline 3.63 & 0.00 \\
\hline
\end{tabular}

\begin{tabular}{|c|c|c|c|}
\hline \multicolumn{2}{|c|}{ 機材保有数 } & 空港運営利潤 & \\
\hline $\mathrm{m}=1$ & $m=2$ & 航空利潤計 & 15168 \\
\hline 3.66 & 0.45 & 代替利潤 & 16557 \\
\hline & & 旅客総費用 & \\
\hline & & 社会的厚生 & 2290 \\
\hline
\end{tabular}

\begin{tabular}{|l|r|}
\hline 空港運営利潤 & 0 \\
航空利潤計 & 16740 \\
代替利潤 & 15656 \\
旅客総費用 & -54139 \\
\hline 社会的厚生 & -21744 \\
\hline
\end{tabular}

\begin{tabular}{|l|r|}
\hline 空港運営利閨 & 0 \\
航空利潤計 & 21908 \\
代替利潤 & 9653 \\
旅客総費用 & -62497 \\
\hline 社会的厚生 & -30936 \\
\hline
\end{tabular}

\begin{tabular}{|l|r|}
\hline 空港運営利潤 & 0 \\
航空利潤計 & 20364 \\
代替利潤 & 15337 \\
旅客総費用 & -64087 \\
\hline 社会的厚生 & -28386 \\
\hline
\end{tabular}

\begin{tabular}{|l|r|}
\hline 空港運営利潤 & 0 \\
航空利潤計 & 23561 \\
代替利潤 & 15935 \\
旅客総費用 & -71500 \\
\hline 社会的厚生 & -32004 \\
\hline
\end{tabular}

\begin{tabular}{|l|r|}
\hline 空港渾営利潤 & 0 \\
\hline 航空利潤計 & 25341 \\
代替利潤 & 10402 \\
旅客総費用 & -67612 \\
\hline 社会的厚生 & -31869 \\
\hline
\end{tabular}

\begin{tabular}{|l|r|}
\hline 空港運営利潤 & 0 \\
航空利潤計 & 21684 \\
代替利潤 & 4419 \\
旅客総費用 & -56806 \\
\hline 社会的厚生 & -30702 \\
\hline
\end{tabular}




\section{(3)空港使用料政策に関する考察}

ここでは，全国一律の空港使用料が設定される場合上 空港毎に異なる空港使用料が設定される場合とを比較し, 空港使用料政策について考察を行う。ただし，表-5 のケ 一ス名は，表-4 の各ケースと同じパラメータを用いたと いう意味で，それに対応するように””をつけている。

まずケース 1 と比較してケース 1 では，路線 1 を排除 するような空港使用料が設定され，さらに空港 2 が内部 補助を受ける，そのとき，航空会社利潤・旅客の総費用 は悪化するが, 代替モード利潤・空港運営利潤が増加す るため, 社会的厚生は改善される。

ケース $2 \cdot 2$ 2は路線 3 が複占になる場合の計算結果で ある. ケース 2 上 2 を比較して, 路線網の形状自体は変 化しない. しかし，各空港毎に使用料が設定されるとき には，全空港一律の使用料が設定されるよりも路線 2 の 航空便数が減少し, 路線 3 の航空便数が増加している. その結果, 全空港一律の使用料が設定される場合に比べ 社会的厚生は改善される.ただし，その改善分の殆どは 空港運営利潤であり, 旅客の総費用等は増加している.

ケース $3 \cdot 3$ 3は路線 2 が複占になった場合である.ケ 一ス 3 と比較してケース 3’では, 空港毎に異なる空港使 用料が設定され, 路線 2 の便数が減少し, 路線 3 の便数 が増加する。 その結果, 空港運営利潤・航空会社利潤は 減少するが，代替モード利潤の増加・旅客総費用の減少 により社会的厚生は増加する。

ケース $4 \cdot 4$ は, 全路線が複占になった場合の計算結 果である.このときケース 4 と比較して, ケース 4 では 空港 1 での使用料が高く設定される.さらに，各空港毎 に異なる空港使用料が設定されることで, 代替モードが あまり整備されていない路線 2 への割り当てを優先させ るような使用料の設定が行われ，ケース 4 よりも高い社 会的厚生が详成される。

紙面の都合上割愛するが， $\alpha$ が極端に低く，代替モ一 ドが十分整備されている状況の下では，航空モードは排 除される。これは, 航空モードの導入による旅客の総時 間費用減少より，運航費用や空港での費用増分の方が大 きいためである.

以上から得られた結論を, 空港毎に異なる空港使用料 が設定される場合の結果を全空港一律の空港使用料が設 定される場合の結果に対比させることで以下に示す。

1.全空港一律の空港使用料の設定と対比して, 空港別に異 なる空港使用料が設定される場合には, 社会的厚生は改 善される。

2.政府は，OD 交通量が他と比べて極めて少ないゾーン間 での航空の直行便運航を排除する.

3.OD 交通量が多いゾーン間を結ぶ直行便運航について,

代替モードが相対的に整備されていない路線で航空モー ドの頻度を増加させるように（内部補助の可能性も含め
て）空港使用料を変化させることにより，航空会社を誘 導し，より高い社会的厚生を達成する.

4.空港容量制約が有効である場合，代替モードがあまり整 備されていない路線への割り当てを優先させるような空 港使用料を設定することにより，高い社会的厚生を達成 できる。

5.旅客の時間価値パラメータ《が低い場合や，代替モード が十分整備されている場合には，政府は航空モードを排 除する。

\section{4. 結論}

本研究では, 航空市場を政府・航空会社・旅客の行動 として記述し, 市場均衡解を数値分析により導出し, 前 半ではハブ・スポークネットワークの形成, 後半では空 港使用料政策について考察を行った ${ }^{10}$

まずハブ・スポークネットワーク形成に関する結論と しては，旅客の一般化費用が直行便に比べて乗り継ぎル ートの方が (十分) 低い場合にハブ・スポークネットワ ークが形成されることが明らかにされた。これは，既存 研究で指摘されている航空会社の費用特性とは無関係に 成立する. 乗り継ぎルートの一般化費用が直行便のそれ と比較して低くなるのは，乗り継ざルートを構成する路 線に対して企業参入が行われる場合上 OD 交通量が相対 的に少ない $\mathrm{OD}$ が存在する場合である.

ただし航空経済学者の中には，「限られた機材でネッ トワークを拡大するため, 航空会社はハブ・スポークネ ットワークを形成する．」との指摘もある。これはより 多くの都市を結ぶことで, 航空会社は誘発需要や転換需 要を喚起することができ，その結果利潤を上昇させるこ とを意味すると言えよう。この効果を考慮するためには， (1)OD交通量の内生化及び2路線数や便数の多寡による旅 客の多様性選好の導入，(3)ルート毎に航空運賃が決定さ れるようなモデルへの拡張が必要である. 従って, 本研 究ではハブ・スポークネットワークの形成要因上しては その一部が明らかにされたに過ぎない.しかし，航空ネ ットワーク形成に関して, 既存研究では航空会社側の要 因のみが注目されていたという点において, 旅客側の要 因からもハブ・スポークネットワーク形成の可能性を示 せたことは，重要な示唆となりうるであろう。

次に空港使用料政策に関する分析の結論として, 全空

10 ハブ・スボークネットワークは，米国の規制緩和以降に観察さ れた路線網の形態の一つである. 現実には，後背地域に大規模な 需要がある場合だけでなく, 空港運営主体の誘致により, ハブ空 港ができる場合もある. 本稿ではブ・スポークネットワーク形 成には需要側の要因のみか関係していることか明らかにされたが, 今後は上述のような空港運営側等の要因も考慮した上で議論する 必要があろう。 
表-4 空港使用料政策の評価（全空港一律の使用料の場合）

ケース $1\left(\alpha=0.4, f_{0}^{1}=2, f_{0}^{2}=20, f_{0}^{3}=10\right)$

\begin{tabular}{|r|c|r|r|r|r|}
\hline 路線 & 航空 & \multicolumn{2}{|c|}{ 航空便数 } & \multicolumn{2}{|c|}{ 旅客数 } \\
\cline { 3 - 6 } & 運傊 & $\mathrm{m}=1$ & $\mathrm{~m}=2$ & 航空計 & 代替 \\
\hline 1 & 3.75 & 1.50 & 0.00 & 425 & 86 \\
2 & 2.42 & 18.26 & 0.00 & 5479 & 7010 \\
3 & 3.27 & 17.17 & 0.00 & 5151 & 3339 \\
\hline
\end{tabular}

\begin{tabular}{|r|r|r|}
\hline 空港 & \multicolumn{2}{|c|}{ 空港使用料 } \\
\cline { 2 - 3 } & $\mathrm{m}=1$ & $\mathrm{~m}=2$ \\
\hline 1 & 40 & 35 \\
2 & 40 & 35 \\
3 & 40 & 35 \\
\hline
\end{tabular}

\begin{tabular}{|c|c|}
\hline \multicolumn{2}{|c|}{ 機材保有数 } \\
\hline $\mathrm{m}=1$ & $\mathrm{~m}=2$ \\
\hline 4.44 & 0.00 \\
\hline
\end{tabular}

\begin{tabular}{|l|r|}
\hline 空港運営利潤 & 0 \\
航空利潤計 & 23561 \\
代替利潤 & 15935 \\
旅客総費用 & -71500 \\
\hline 社会的厚生 & -32004 \\
\hline
\end{tabular}

ケース 2 (路線 3 のみ複占, $\alpha=0.4, f^{1}=2, f^{2}=20, f^{3}=10$ )

\begin{tabular}{|r|c|c|c|r|r|}
\hline 路線 & 航空 & \multicolumn{2}{|c|}{ 航空便数 } & \multicolumn{2}{|c|}{ 旅客数 } \\
\cline { 3 - 6 } & 運盾 & $\mathrm{m}=1$ & $\mathrm{~m}=2$ & 航空計 & 代替 \\
\hline 1 & - & - & - & 0 & 42 \\
2 & 2.28 & 20.54 & 0.00 & 6162 & 6571 \\
3 & 2.24 & 14.82 & 0.00 & 8424 & 941 \\
\hline
\end{tabular}

\begin{tabular}{|r|r|r|}
\hline 空港 & \multicolumn{2}{|c|}{ 空港使用料 } \\
\cline { 2 - 3 } & $\mathrm{m}=1$ & $\mathrm{~m}=2$ \\
\hline 1 & 40 & 35 \\
2 & 40 & 35 \\
3 & 40 & 35 \\
\hline
\end{tabular}

\begin{tabular}{|c|c|}
\hline \multicolumn{2}{|c|}{ 機材保有数 } \\
\hline$m=1$ & $m=2$ \\
\hline 4.13 & 0.00 \\
\hline
\end{tabular}

\begin{tabular}{|l|r|}
\hline 空港運営利潤 & 0 \\
航空利潤計 & 21908 \\
代替利潤 & 9653 \\
旅客総費用 & -62497 \\
\hline 社会的厚生 & -30936 \\
\hline
\end{tabular}

\begin{tabular}{r|r|c|c|r|r|} 
ケース 3(路線 2 の 複占, $\alpha=0.4, \quad f_{0}^{1}=2, f^{2}$ \\
\hline 路線 & 航空 & \multicolumn{2}{|c|}{ 航空便数 } & \multicolumn{2}{|c|}{ 旅客数 } \\
\cline { 3 - 6 } & 運賃 & $\mathrm{m}=1$ & $\mathrm{~m}=2$ & 航空計 & 代替 \\
\hline 1 & - & - & - & 0 & 85 \\
2 & 2.07 & 15.51 & 0.00 & 9268 & 4043 \\
3 & 3.18 & 18.75 & 0.00 & 5620 & 3179 \\
\hline
\end{tabular}

\begin{tabular}{|r|r|r|}
\hline 空港 & \multicolumn{2}{c|}{ 空港使用料 } \\
\cline { 2 - 3 } & $\mathrm{m}=1$ & $\mathrm{~m}=2$ \\
\hline 1 & 69 & 38 \\
2 & 69 & 38 \\
3 & 69 & 38 \\
\hline
\end{tabular}

\begin{tabular}{|c|c|c|c|}
\hline \multicolumn{2}{|c|}{ 機材保有数 } & \multirow{2}{*}{$\begin{array}{l}\text { 空港運営利潤 } \\
\text { 航空利潤計 }\end{array}$} & \multirow{2}{*}{$\begin{array}{r}2887 \\
23397\end{array}$} \\
\hline $\mathrm{m}=1$ & $\mathrm{~m}=2$ & & \\
\hline 4.06 & 0.00 & 代替利潤 & 11408 \\
\hline & & 旅客， & -69660 \\
\hline & & 社会的厚生 & -3196 \\
\hline
\end{tabular}

ケース 4(全路線複占, $\alpha=0.4, f_{0}^{1}=2, f_{0}^{2}=20, f_{0}^{3}=10$ )

\begin{tabular}{|c|c|c|c|c|c|c|c|c|}
\hline \multirow[t]{2}{*}{ 路線 } & \multirow{2}{*}{$\begin{array}{l}\text { 航空 } \\
\text { 運賃 }\end{array}$} & \multicolumn{2}{|c|}{ 航空便数 } & \multicolumn{2}{|c|}{ 旅客数 } & \multirow[t]{2}{*}{ 空港 } & \multicolumn{2}{|c|}{ 空港使用料 } \\
\hline & & $m=1$ & $m=2$ & 航空計 & 代替 & & $m=1$ & $m=2$ \\
\hline 1 & - & - & - & 0 & 64 & 1 & 192 & 139 \\
\hline 2 & 2.61 & 12.45 & 0.00 & 7384 & 5594 & 2 & 192 & 139 \\
\hline 3 & 2.92 & 12.52 & 0.00 & 7438 & 1659 & 3 & 192 & 139 \\
\hline
\end{tabular}

\begin{tabular}{|c|r|}
\hline \multicolumn{2}{|c|}{ 機材保有数 } \\
\hline$m=1$ & $m=2$ \\
\hline 2.95 & 0 \\
\hline
\end{tabular}

\begin{tabular}{|l|r|}
\hline 空港運営利潤 & 15178 \\
航空利潤計 & 14945 \\
代替利潤 & 10010 \\
旅客総費用 & -71684 \\
\hline 社会的厚生 & -31551 \\
\hline
\end{tabular}

表-5 空港使用料政策の評価（空港別使用料の場合）

ケース $1^{\prime}\left(\alpha=0.4, f_{0}^{1}=2, f_{0}^{2}=20, f_{0}^{3}=10\right)$

\begin{tabular}{|r|c|c|c|r|r|}
\hline 路線 & 航空 & \multicolumn{2}{|c|}{ 航空便数 } & \multicolumn{2}{|c|}{ 旅客数 } \\
\cline { 3 - 6 } & 運覒 & $\mathrm{m}=1$ & $\mathrm{~m}=2$ & 航空計 & 代替 \\
\hline 1 & - & - & - & 0 & 146 \\
2 & 2.47 & 18.28 & 0.00 & 5484 & 7371 \\
3 & 3.19 & 18.54 & 0.00 & 5560 & 3294 \\
\hline
\end{tabular}

\begin{tabular}{|r|r|r|}
\hline 空港 & \multicolumn{2}{|c|}{ 空港使用料 } \\
\cline { 2 - 3 } & $\mathrm{m}=1$ & $\mathrm{~m}=2$ \\
\hline 1 & 53 & 35 \\
2 & 0 & 0 \\
3 & 7.3 & 53 \\
\hline
\end{tabular}

\begin{tabular}{|c|r|}
\hline $\mathrm{m}=1$ & $\mathrm{~m}=2$ \\
\hline 4.35 & 0 \\
\hline
\end{tabular}

\begin{tabular}{|l|r|}
\hline 空港運営利潤 & 340 \\
航空利潤計 & 22897 \\
代替利潤 & 16545 \\
旅客総費用 & -71688 \\
\hline 社会的厚生 & -31906 \\
\hline
\end{tabular}

\begin{tabular}{|c|c|c|c|c|c|}
\hline \multirow[t]{2}{*}{ 路線 } & \multirow{2}{*}{$\begin{array}{l}\text { 航空 } \\
\text { 運賃 }\end{array}$} & \multicolumn{2}{|c|}{ 航空便数 } & \multicolumn{2}{|c|}{ 旅客数 } \\
\hline & & $m=1$ & $m=2$ & 航空計 & 代替 \\
\hline 1 & - & - & - & 0 & 45 \\
\hline 2 & 2.37 & 19.60 & 0.00 & 5869 & 6853 \\
\hline 3 & 2.25 & 14.28 & 0.00 & 8386 & 956 \\
\hline
\end{tabular}

\begin{tabular}{|r|r|r|}
\hline 空港 & \multicolumn{2}{|c|}{$\left.f^{3}=10\right)$} \\
\cline { 2 - 3 } & $\mathrm{m}=1$ & $\mathrm{~m}=2$ \\
\hline 1 & 56 & 16 \\
2 & 38 & 27 \\
3 & 72 & 45 \\
\hline
\end{tabular}

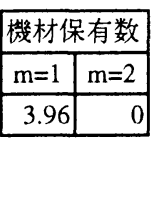

\begin{tabular}{|l|r|}
\hline 空港運営利潤 & 1340 \\
航空利潤計 & 20889 \\
代替利潤 & 10089 \\
旅客総費用 & -63092 \\
\hline 社会的厚生 & -30774 \\
\hline
\end{tabular}

\begin{tabular}{|r|c|c|c|r|r|}
\hline 路線 & 航空 & \multicolumn{2}{|c|}{ 航空便数 } & \multicolumn{2}{|c|}{ 旅客数 } \\
\cline { 2 - 6 } & 運賃 & $\mathrm{m}=1$ & $\mathrm{~m}=2$ & 航空計 & 代替 \\
\hline 1 & - & - & - & 0 & 81 \\
2 & 2.12 & 15.22 & 0.00 & 9132 & 4197 \\
3 & 3.05 & 19.65 & 0.00 & 5873 & 2920 \\
\hline
\end{tabular}

\begin{tabular}{|r|r|r|}
\hline 空港 & \multicolumn{2}{|c|}{$f^{3}=10$ ) } \\
\cline { 2 - 3 } & $\mathrm{m}=1$ & $\mathrm{~m}=2$ \\
\hline 1 & 34 & 38 \\
2 & 0 & 0 \\
2 & 0 & \\
3 & 128 & 68 \\
\hline
\end{tabular}

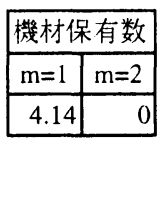

\begin{tabular}{|l|r|}
\hline 空港運営利潤 & 1592 \\
航空利潤計 & 24914 \\
代替利潤 & 11016 \\
旅客総費用 & -69324 \\
\hline 社会的厚生 & -31802 \\
\hline
\end{tabular}

\begin{tabular}{|r|c|c|c|r|r|}
\hline 路線 & 航空 & \multicolumn{2}{|c|}{ 航空便数 } & \multicolumn{2}{|c|}{ 旅客数 } \\
\cline { 3 - 6 } & 運傮 & $\mathrm{m}=1$ & $\mathrm{~m}=2$ & 航空計 & 代替 \\
\hline 1 & - & - & - & 0 & 59 \\
2 & 2.65 & 12.10 & 0.00 & 7260 & 5716 \\
3 & 2.80 & 12.69 & 0.00 & 7612 & 1497 \\
\hline
\end{tabular}

\begin{tabular}{|r|r|r|}
\hline 空港 & \multicolumn{2}{|c|}{ 空港使用料 } \\
\cline { 2 - 3 } & $\mathrm{m}=1$ & $\mathrm{~m}=2$ \\
\hline 1 & 243 & 195 \\
2 & 95 & 70 \\
3 & 158 & 95 \\
\hline
\end{tabular}

\begin{tabular}{|c|r|}
\hline $\mathrm{m}=1$ & $\mathrm{~m}=2$ \\
\hline 2.93 & 0 \\
\hline
\end{tabular}

\begin{tabular}{|l|r|}
\hline 空港運営利潤 & 14315 \\
航空利潤計 & 15674 \\
代替利潤 & 9794 \\
旅客総費用 & -70838 \\
\hline 社会的厚生 & -31355 \\
\hline
\end{tabular}


港一律の空港使用料が設定される場合と比べて，空港毎 に異なる空港使用料が設定される場合には，(1)社会的厚 生を改善すること, (2)政府は社会的厚生の観点から需要 の小規模なローカル線運航を排除するような空港使用料 を採用すること、(3)代替モードがあまり整備されていな い幹線を抱える空港では空港使用料が低く設定され, 結 果として内部補助を受ける場合があること等か確認され た. ただし(2)は，離島路線を排除することは意味しない。 何故なら, 本稿ではローカル線が排除されても, 代替モ 一ドや乗り継ぎルートを利用することにより，目的地一 到達できるからである. (3)は, 空港使用料低下による運 賃低下 · 便数増加を促すことで旅客の一般化費用を低下 させる効果が, 代替モードのあまり整備されていない路 線を有す空港で大きかった為である.

ただし, 空港使用料政策について論じるためには, 空 港混雑の考虑が本質的に重要である. その意味において, 以上の分析には問題がある. しかし空港混雑が無くとも, 全国一律の空港使用料設定が社会的厚生の観点から好ま しくないことを示せたことは，現行の日本における空港 使用料政策に関して問題があることを明らかにさせたと 言えよう。この意味において本稿の結論は, 日本の空港 政策に関して一つの問題提起が出来たと考之られる. 勿 論, 日本の空港政策の問題点は, 最初に述べたように空 港整備特別会計や燃料税の分配等の制度にある。この点 に関して議論するためには, 政府が空港整備を行うよう な枠組みへの拡張が必要である.

さらに本稿の枠組みでは，政府が全空港を所有すると 仮定した，これを日本に当てはめると，空港は第1-3種に 分類され, 運営主体も政府単独, 政府と地方自治体, 地 方自治体のみの場合があり，必ずしも国が全空港を所有 しているわけではない. しかし, 空港整備特別会計の存 在や同一空港使用料の採用と言う観点から言えば，近似 的にはこのような仮定も容認されよう。このように，本 研究には多くの課題が存在するものの, 空港発着枠市場 と旅客市場とを航空市場として扱い，数値分析を通じて 航空市場構造等に関する分析可能性について示せたこと は, 航空市場分析の発展に貢献できたと思われる.

今後の課題としては, OD交通量内生化や空港混雑の導 入及び大規模ネットワークでの分析が必要であろう。こ れらのことを考慮することで，より一般性を有した分析 が可能となるであろう。

謝辞: ARSC1997年発表大会の討論者である山内弘隆氏 (一 橋大学), 匿名の査読者, 佐々木公明, 文世一, 森杉壽 芳, 稲村肇の各氏 (東北大学) には, 多くの有益なコメ ントを頂いた，記して感謝の意を表します。本稿の有り 得べき誤りは筆者に帰属します。

\section{付録1}

航空会社の費用特性として，輸送密度の経済性や機材 規模の経済性が慟いていることが実証されている(17) 181.19). 輸送密度の経済性にはCaves et al.(1984)の定義とBrueckner and Spiller(1991)の定義がある゙．前者では, 総費用のイン プットに対寸る弾力性が1より小さい性質を輸送密度の経 済性が働く上定義されて扔り，後者ではリンクでの運航 費用がリンク交通量に関して派減的に增加する性質を輸 送密度の経済性が働く上定義されている，既存の理論的 研究では，モデルに輸送密度の経済性を導入する上き， 後者の定義が採用されることが殆どである. ところで, Brueckner and Spiller(1991)流の輸送密度の経済性は, Hendricks他(1995)の解釈以外にも，リンク交通量の増加に 伴い使用機材が大型化し，旅客一人当たりに換算した運 航費用が減少することを意味するとも解釈可能である. この解釈は，村上 $(1994)^{30}$ の定義での機材の大型化による 経済性（以下，機材規模の経済性と呼ぶ）に他ならない. 本稿では, Brueckner and Spiller(1991)の言うc" $(\cdot)<0 を$ 機材 規模の経済性と解釈した上で分析を進める。

次に, 船舶輸送を想定し, 輸送密度の経済性を考慮し た理論研究として, Mori and Nishikimi(1997) ${ }^{21)}$ やUeda et al $(1997)^{2)}$ がある，前者は，輸送密度の経済が㗢いている 場合に，ハブ・スポークネットワークの形成を通じて地域 間交易が行われる可能性を，複数均衡の可能性上共に明 らかにしているが，交通企業は明示的に扱われていない。 後者は，地域間の交易量が与えられた下で，輸送密度の 経済性とハブ・スポークネットワークの形成の関係と共に 港湾施設の利用料について分析が行われている. ただし, 彼らのモデルで交通企業は, price-takerとして行動する. さらに, 港湾運営会社の設定する港湾使用料は, 自然独 占を理由に政府により平均価格に規制されるとし，何ら かの理由により，港湾使用料を引き下げるために政府か ら港湾運営会社は補助金を受け取る設定になっている。 しかし, 社会的厚生関数の定義で, 港湾運営会社へ補助 金が与えられるにもかかからず，社会全体からその補助 金は差し引かれていないところに問題があろう.

さらにKonishi(1998) 231 は，3都市からなる単純な一般均 衡モデルにより, 規模の経済性を考虑しなくても，1都市 を経由する輸送費が低下すれば八ブが形成され，荷役労 働の必要性が人口集中をもたらすことを示した．そこで は交通需要は財需要に伴う派生需要として扱われ, 交通 事業者は主体として考慮されないという点で，事業者の 寡占性が強い航空市場とは異なる。長期的には路線設定 が人口の再配置に通じる可能性はあるが，航空会社の戦 略は既存の交通需要を如何に効率的に取り込む加にある

\footnotetext{
${ }^{11}$ Brueckner and Spiller(1991)の定式化はネットワーク依存であり, 一つの OD に複数ルートが存在する場合には適用できない.
} 
と考えられるから，このモデルの枠組みを直ちに航空市 場の分析に援用することは難しいと考えられる.

\section{付録 2}

旅客の行動に関する仮定の詳細は大橋・安藤(1996)を参 照されたい. まず, 簡単のため以下の仮定を導入する.

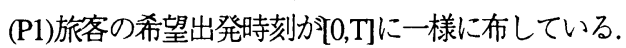

(P2)旅客は，ある特定のリンクで，企業が異なれば異なる ルートとして認識し，乗り継ぎも考慮する。

(P3)仮定(P1), (M5)より, 旅客の平均時間費用 ${ }^{155}$, 24)は以下 のように与えられる.

$t^{r}=\sum_{(l, a) \in L(r)}\left(t_{a}^{l}+T / 4 \sum_{m \in M} f_{a m}^{l}\right)$ for $i, j \in I, r \in R(i, j)$

ここに, $t_{a}^{l}$ :ラインホール時間, $f_{a m}^{l}$ :便数とする.

(P4)旅客の一般化費用は，運賃とパラメータ $\alpha$ にるる時間 費用の金銭換算值の線形結合として表される.

上述の仮定の下で，旅客のルートから得られる効用が $\mathrm{ij}$ 間を旅行することにより得られる効用と一般化費用, 及 ひ確率的なルートへの効用 $\varepsilon^{r}$ の線形結合として表される とする.ささら $\varepsilon^{\prime}$ が独立で同一のワイブル分布 $(\eta+.5771$ $\left.\omega, \pi / 6^{0.5} \omega\right)$ に従い， $\eta=0$ とする.ここに $\eta$ はモード, $\omega$ は分散パラメータとする. このような仮定の下で旅客 のルート選択行動は式(1)或いは(1')のように表される.

\section{付録3}

(7)のラグランジュ関数は, 以下のように書ける.

$$
\begin{aligned}
\Phi_{a} & =\pi_{a}+\sum_{l \in \Omega(a)} \mu_{a}^{l}\left(\sum_{m \in M} f_{a m}^{l} V_{m}-x_{a}^{l}\right) \\
& +\sum_{m \in M} \lambda_{a}^{m}\left\{K_{a}^{m} T-\sum_{l \in \Omega(a)}\left(t_{a}^{l}+T S\right) f_{a m}^{l}\right\}+\delta_{a}^{l} \prod_{\substack{m^{\prime} \in M \\
m^{\prime} \in m}} f_{a m^{\prime}}^{l}
\end{aligned}
$$

ここでKuhn-Tucker条件から, 運賃·便数 ·機材保有数が 共に正ならば, これらに対する一階の条件は,

$$
\begin{gathered}
\frac{\partial \Phi_{a}}{\partial p_{a}^{l}}=x_{a}^{l}+\sum_{l^{\prime} \in \Omega(a)}\left(p_{a}^{l^{\prime}}-\mu_{a}^{l^{\prime}}-S C_{a}^{l^{\prime}}\right) \frac{\partial x_{a}^{l^{\prime}}}{\partial p_{a}^{l}}=0 \\
\frac{\partial \Phi_{a}}{\partial f_{a m}^{l}}=\sum_{l^{\prime} \in \Omega(a)}\left(p_{a}^{l^{\prime}}-\mu_{a}^{l^{\prime}}-S C_{a}^{l^{\prime}}\right) \frac{\partial x_{a}^{l^{\prime}}}{\partial f_{a}^{l}} \\
-\left(H_{m}^{l}+O C_{a m}^{l}\right)-\lambda_{a}^{m}\left(t_{a}^{l}+T S\right)+\mu_{a}^{l} V_{m}-\prod_{\substack{m^{\prime} \in M \\
m \neq m}} f_{a m^{\prime}}^{l}=0 \\
\frac{\partial \Phi_{a}}{\partial K_{a}^{m}}=-k_{m}+T \lambda_{a}^{m}=0
\end{gathered}
$$

と書くことが出来る. ここで,

$$
\frac{\partial x_{a}^{l^{\prime}}}{\partial p_{a}^{l}}=M 1^{l^{\prime} a}, \frac{\partial x_{a}^{l^{\prime}}}{\partial f_{a}^{l}}=-\frac{\alpha T}{4\left(\sum_{m \in M} f_{a m}^{l}\right)^{2}} M 1^{l^{\prime} a}
$$

とおく、ただし，

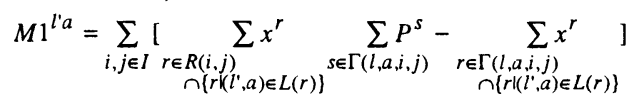

である. $\Gamma(l, a, i, j)$ は, $(i, j)$ 所与の下で準択可能なルート の内， $(l, a)$ を構成要素とする集合，すなわた， $\Gamma(l, a, i, j)=\{r \in R(i, j) \mid(l, a) \in L(r)\}$ である. $M 1^{i a}$ に含 まれる $P^{r}, x^{r}$ はそれぞれ $p_{a}^{l}, f_{a m}^{l}$ の関数である.

\section{付録4}

旅客の便益は，次のように書き換えられる。.

$$
-\sum_{i, j \in I} \sum_{r \in R(i, j)} \frac{1}{\omega} x^{r} \ln P^{r}+\sum_{i, j \in I} \sum_{r \in R(i, j)}\left(U_{i j}-B^{r}\right) x^{r}
$$

数値計算では, 旅客の便益を確定項のみで評価する。こ こで, 確定項についてOD交通量が外生的に与えられるた め, OD間で得られる効用は一定であるから，ルートから， 得られる純便益は，（差し引く項目としての）旅客の総 費用の和にのみ依存することになる。 そこで $U_{i}=0$ とし， さらに $\omega=1$ を仮定している.

\section{付録5}

問題(14)は，旅客市場の均衡条件付き最適化問題である が，政府が企業や旅客の情報をすべて把握しているとい う意味で，政府に過剩な情報の優位性を認めている。 上 ころで, 均衡条件付き最適化問題には，シュタッケルベ ルグ問題と呼ばれるものがある.ただし問題(14)は，シュ タッケルベルグ問題とは異なる，その理由についてシュ タッケルベルグ均衡を解説することにより説明しよう.

シュタッケルベルグ均衡とは, 不完全競争の下での企 業間競争の一形態上して捉えることができる. まず市場 参加企業に先導者 1 名と追随者 1 名が存在する. ここで追 随者は, 自己が行動するとき, 他社の行動か湾化しない 上推測（クールノーの仮定）し, 先導者は, 他社がクー ルノーの仮定に従って行動するということを知っている.

このような状況の下での均衡のことをシェタッケルベル グ均衡と呼ばれている.

この関係をゲーム論的に解釈しょう. 先導者は政府で （1主体）で追随者は航空会社（複数）であり，この追随 者に追随する旅客 (多数) が存在する.このように本稿 のモデルはシュタッケルベルグ問題をより拡張したもの であると言える。

他方，市場参加主体の関係を経済学的に見ると，前述 のように政府と航空会社の間には空港発着枠に関する需 給関係（空港発着枠市場），航空会社上旅客の間には座 席に関する需給関倸（代替モードも含めて旅客市場）が ある。これら各需給関係は「市場」上呼ばれる。

\section{付録 6}

数値計算では，ペナルティ法を用いたアルゴリズムを 採用している25. まず問題(14)の目的関数の勾配は, 


$$
\begin{aligned}
& \nabla_{H_{n m}} W_{f}\left(H_{n m}, \eta_{a}\left(H_{n m}\right)\right) \\
& =\nabla_{H_{n m}} W_{f}+\sum_{a \in A_{0}} \nabla_{\eta_{a}} W_{f} \cdot \nabla_{H_{n m}} \eta_{a} \\
& =\nabla_{H_{n m}} W_{f}-\sum_{a \in A_{0}} \nabla_{\eta_{a}} W_{f}\left[\nabla_{\eta_{a} \eta_{a}}^{2} P_{e n_{a}}\right]^{-1} \nabla_{H_{n} \eta_{a}}^{2} P_{e n_{a}}
\end{aligned}
$$

のように $(1 \times \mathrm{n})$ のベクトルとして表せる. 同様に制約条件 のJacobianは $(\mathrm{m} \times \mathrm{n})$ の)行列として ,

$$
\begin{aligned}
& \nabla_{H_{n m}} g_{n}\left(H_{n m}, \eta_{a}\left(H_{n m}\right)\right) \\
& =\nabla_{H_{n m}} g_{n}+\sum_{a \in A_{-} 0} \nabla_{\eta_{a}} g_{n} \cdot \nabla_{H_{n m}} \eta_{a} \\
& =\nabla_{H_{n m}} g_{n}-\sum_{a \in A_{-0}} \nabla_{\eta_{a}} g_{n}\left[\nabla_{\eta_{a} \eta_{a}}^{2} \text { Pen }_{a}\right]^{-1} \nabla_{H_{n} \eta_{a}}^{2} \text { Pen }_{a}
\end{aligned}
$$

のように表すことが出来る．ただし，Pen 直面する問題のペナルティ関数である.

プログラム設計の際, 企業は余分な機材を保有する誘 因を持たないため，機材制約が有効であると想定してい る. 次に問題(7)の計算では機種の総数を路線の数だけ掛 け合わせた分についてそれぞれ計算を行い，航空会社利 潤について比較を行い, 利潤が最大となる運貨 ·便数の 組み合わせを求めている.

なお，本稿のモデルでは，一般的に解の唯一性は保証 されない. 従って数值解は, 各パラメータの組の下での1 つの解を示すもので, 他の解の存在を排除するものでは ない. しかし，これら局所解の回りで微少な擋乱を与え た場合の局所的安定性は数値的に確認している. 解の唯 一性・安定性に関する理論的検討は今後の課題としたい。

\section{参考文献}

1) 金本良嗣, 山内弘隆:「講座·公的規制と産業4; 交通」,4章, NTT出版, 1995.

2) Bittlingmayer, G.: Efficiency and entry in a simple airline network, International Journal of Industrial Organization, vol.8, pp.245257, 1990.

3) Brueckner, J.K. and Spiller, P.T.: Competition and mergers in airline networks, Intermational Journal of Industrial Organization, vol.9, pp.323-342, 1991.

4) Nero, G.: A structural model of intra European Union duopoly airline competition, Joumal of Transpon Economics and Policy, vol.30 (2), pp.137-155, 1996.

5) Zhang, A.: An analysis of fortress hubs in airline networks, Joumal of Transport Economics and policy, vol.30(3), pp.293$307,1996$.

6) Hendricks, K., Piccione, M. and Tan, G.: The economics of hubs; the case of monopoly, Review of Economic Studies, vol.62, pp.8399, 1995.
7) 前掲3)

8) Hansen, M.: Airline competition in a hub-dominated environment: an application of noncooperatative game theory, Transpontation Research, Vol.24(1)-B, pp.27-43, 1990.

9) 例えば，稲村晵，久永幸之: 航空機材スケジューリングの ためのニューラルネットワークの開発, 土木学会論文集. vol.IV-31, pp.9-21, 1996.

10)航空政策研究会:「現代の航空輸送」. 勁草書房. 1995 .

11)Borenstein, S.: Airline mergers, aiport dominance, and market power, American Economic Review, vol.80(2), pp.400-4(14, 199().

12)Morrison, S.A. and Winston, C.: The Evolution of Airline Industry. Washington. D.C.,: Brookings Institution. 1995.(郭賢泰訳:「規 制緩和の経済効果」，第一部。日本評論社. 1997.)

13)加藤雅: 「規制緩和の経済学」。第6章, 東洋経済新報社, 1994

14)Oum, T.H., Zhang, A. and Zhang, Y.: A note on optimal airport pricing in a hub-and-spoke system, Transportation Research, vol. 30(1) -B, pp.11-18, 1996.

15)大橋忠宏, 安藤朝夫: ネットワークを考慮した航空旅客市 場と航空政策のモデル分析, 応用地域学研究. Vol.2, pp.133 144,1996

16)Sasaki, K.: Travel demand and the evaluation of transportation system change; a reconsideration of random utility approach, Environmental Planning A, vol.14 pp.169-182, 1982.

17)Caves, W.C., Cluristensen, L.R. and Tretheway, M.W.: Economies of density versus economies of scale; why trunk and local service airline costs differ, RANI) Journal of Economics, vol.15(4) pp.471 489, 1984.

18)Brueckner, I.K., Dyer, N.J. and Spiller, P.T.: Fare determination in ailine hub-and-spoke networks, RAND Journal of Economics, vol.23(3), pp.309)-333, 1992.

19)Brueckner, J.K. and Spiller, P.T.: Economies of traffic density in the deregulated airline industry, Journal of Law and Economics, vol.37, pp.379-415, 1994

20)村上英樹：国内航空運賃 - 費用の計量分析，神戸大学経営 学部研究年報, vol.40,pp.67-92, 1994.

21)Mori, T. and Nishikimi, K.: Bulk economies in transportation and industrial location, mimeo,, 11th Applied Regional Science Conference, 1997.

22)Ueda, T., Komori, T., Miyagi, T. and Morisugi, H.: On the benefit of projects for transport network with increasing returns: economic evaluation of hub port development, mimeo. International Symposium on Economic and political Dynamics and Sustainable Development in Asia: Infrastructure as Complex Systems, 1997.

23)Konishi, H.: Hub cities: city formation without economies of scale, Discussion Paper No.A-36, Center for the Study of Complex economic Systems, 1998.

24)Milan, J.: A model of competition between high speed rail and air transport, Transportation Planning and Technology, vol.17, pp.123, 1993.

25)清水清孝: 「多目的と競争の理論」，其立出版，1982.

(1998.1.30受付)

\title{
A STUDY ON THE HUB-SPOKE NETWORK AND LANDING FEE POLICY IN THE AVIATION MARKET
}

Tadahiro OHASHI and Asao ANDO

\begin{abstract}
Passengers, airlines, and airport managers are the agents in the aviation market. Recent economic analyses (on the matter) have mostly been confined to the passenger market, where airline networks are given exogenously. Naturally, such framework is unsuitable for the discussions concerning airport management, or the emergence of hub-spoke networks. In this paper, we construct the behavior-based models for respective participants in the market. Then we identify the condition under which a hub-spoke network is formed, and examine the effect of landing fee policy on the market structure.
\end{abstract}

